\title{
Challenges of shaft excavation in Nepal Himalaya: case study from hydropower projects
}

\author{
Subas Chandra Sunuwar \\ Baneshwor, Kathmandu, Nepal
}

\begin{abstract}
The excavation of the long blind shaft is one of the most difficult and risky in Nepal Himalaya for hydropower development. Excavation of the shaft greater than $200 \mathrm{~m}$ length is a challenge due to vertical or inclined orientation, limited space, available technology and changing geological conditions. Amongst Alimak raise climber, shaft sinking and raise boring excavation methods, Alimak raise climber is most commonly used in Nepal. Selection of excavation method depends on geological conditions, size, length of shaft, access and of course the cost. Pressure shaft of Jhimruk, Khimti I, Chilime, Kaligandagi, Kulekhani, Khani Khola, Upper Tamakoshi and other hydroelectric projects were excavated with the help of conventional Alimak raise climber method. Severe overbreak problems were faced in Khimti I hydropower project during construction of upper inclined pressure shaft whereas recently $214 \mathrm{~m}$ vertical pressure shaft of Upper Tamakoshi and $280 \mathrm{~m}$ vertical pressure shaft of Khani Khola hydroelectric projects in Dolakha have been constructed successfully. Raise boring method was tried in Upper Tamakoshi Project but could not succeed due to deviation of pilot hole and hence shaft sinking and Alimak raise climber were used.
\end{abstract}

Keywords: Pressure shaft, Alimak, raise boring, shaft sinking

Paper Received: 14 April 2015

Paper Accepted: 23 March 2016

\section{INTRODUCTION}

Pressure shaft (penstock) either vertical or inclined is main structure of hydroelectric project. Length and size of the shaft depends on the available head and design discharge. Excavation of the shaft greater than $200 \mathrm{~m}$ length is a challenge due to vertical or inclined orientation and poor geological conditions in Nepal Himalaya. Conventional Alimak raise climber and shaft sinking and mechanised raise boring are common excavation methods. Selection of excavation method depends on geological conditions, size, length of shaft and access. Alimak raise climber is most commonly used in Nepal for pressure shaft excavation. Pressure shaft of Jhimruk, Khimti I, Chilime, Kaligandaki, Kulekhani, Khani Khola, Upper Tamakoshi Hydroelectric projects were excavated by eonventional Alimak raise climber. Severe overbreak problems were faced in Khimti I hydropower project during the construction of upper inclined pressure shaft.

Recently $214 \mathrm{~m}$ vertical pressure shaft of Upper Tamakoshi and $280 \mathrm{~m}$ vertical pressure shaft of Khani Khola hydroelectric projects in Dolakha have been constructed by Alimak raise climber with minor problems. Normally large size and shorter shaft are excavated by shaft sinking method. About $164 \mathrm{~m}$ length vertical shafts were excavated by shaft sinking in Upper Tamakoshi. Raise boring method had tried for deep shaft in Upper Tamakoshi Project but could not succeed due to deviation of pilot hole.

This paper describes challenges, excavation methods and difficulties during construction of the pressure shaft with case studies.

\section{GEOLOGY OF NEPAL HIMALAYA}

The Himalaya is formed as a result of collision between the Indian Plate and the Eurasian Plate that began around 50 million years ago (Kizaki 1994). Today, the Indian plate is constantly moving to the North and converges on Tibet (southern edge of Eurasia) at the rate of $50 \mathrm{~mm} /$ year. This convergence builds up significant stresses to thrust the Indian Plate underneath the Eurasian Plate and pushing the Himalaya upward at a rate of $2-4 \mathrm{~mm} /$ year. It is thus the most active mountain ranges in the world. Hence, it is seismically very active and physiographically very rugged and fragile in nature.

The Nepal Himalaya comprises majority of metamorphic and sedimentary with few granite intrusions. Three major fault systems, namely, Himalayan Frontal Thrust (HFT), Main Boundary Thrust (MBT) and Main Central Thrust (MCT), divide the rocks of the Himalayas into Siwaliks, Lesser Himalaya and Higher Himalaya from south to north (Fig. 1). The MBT and HFT are seismically most active thrusts that can create major problems during construction of any infrastructures. On the other hand, the MCT is not active today and this ductile shear zone had its origin at a deeper crustal level and later brought to the surface by thrusting. Hence, the MCT is shear zone of cataclastic metamorphic rock and will not create any problem. Besides these major faults, there are several minor fault and shear zones. Most of all faults and shear zones systems generally extend from east to west of Nepal, which are oriented parallel to foliation with north dipping. Most serious geological problems in development of infrastructure are generated by faults and shear zones (Sunuwar 2011). These faults and shear zones are responsible for posing 
georisks, and therefore, precise geological model showing faults and shear zones, weak rocks, problematic zones and groundwater condition are crucial for layout selection, design, planning and selection of excavation method for shaft.

$\mathrm{S}$

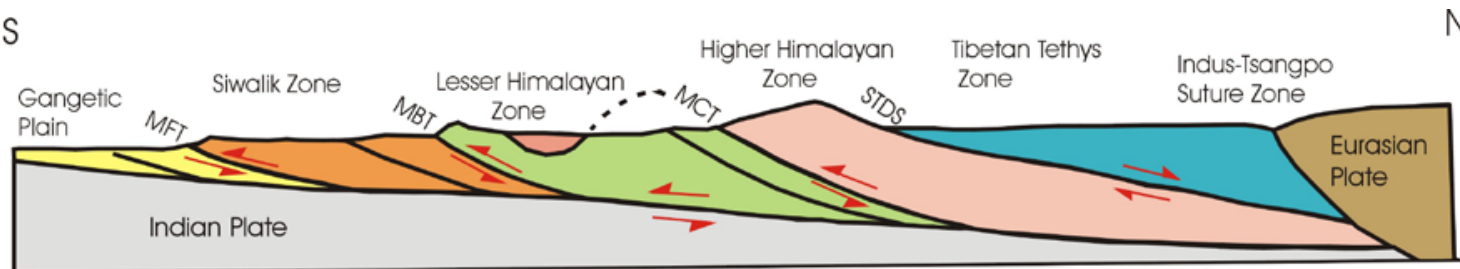

STDS: South Tibetan Detachment System

MCT: Main Central Thrust

MBT: Main Boundary Thrust

MFT: Main Frontal Thrust

Fig. 1: Generalised cross section of the Himalaya showing the major tectonic features of the Nepal Himalaya (Harris and Whalley 2001).

\section{EXCAVATION METHODS}

In the early days normally shaft sinking laborious method was used for excavation. A great step forward was achieved by invention of shaft raising techniques particularly the Alimak raise climber method around 1950. Great advantage of Alimak more than $42^{\circ}$ angle shaft inclination is allowing the muck to slide down itself and no need surface access at top. Similarly, modern Raise boring technology adds great advantage and improves safety. These three excavation methods, Alimak raise climber, Raise boring and Shaft sinking are commonly used for shaft excavation in hydroelectric projects.

\section{Conventional shaft sinking method}

Conventional shaft sinking method are carried out by drill and blast with the help of crane with bucket from the top to bottom. Mucking and dewatering will be laborious and time consuming. These days, problems of mucking and dewatering are solved by excavating pilot hole at centre. Rock support can be provided simultaneously during excavation. Hence this method is safe but sluggish and most commonly used for short and big size shaft excavation. Surge shaft of Andhi Khola, Khimti I, Modi, Kaligandaki, Middle Marsyangdi, Kaligandaki, Mai etc. were excavated by shaft sinking method.

\section{Conventional Alimak raise climber method}

Alimak Company introduced this technique in 1957, and even today it is often used in driving blind raises which have long lengths. The Alimak raise climber is designed to drive raises up to $100 \mathrm{~m}$ long, or more. The important features are: possible to drive very long raises, vertical or inclined, straight or curved and mostly rectangular shape and raise climber can be driven into a safe position using backward guardrails. Because of its features for blowing air and water at the face after blasting, risks of foul gases are eliminated, and the time required for ventilation is reduced. By this method shaft excavation up to $1,200 \mathrm{~m}$ length had been excavated in Norway.

The Alimak raise climber equipment has been still using in Nepal. Recently vertical pressure shaft of Upper Tamakoshi and Khani Khola hydroelectric projects in Dolakha were excavated by Alimak raise climber.

\section{Mechanised Raised boring method}

A raise borer is a machine used in underground mining without the use of explosives developed since 1968. It has capacity to bore length of $1,200 \mathrm{~m}$ with diameter 0.6 to $6 \mathrm{~m}$. These days raise borer has been using to excavate pressure shaft in Hydropower projects.

The raise borer is set up on the upper level where penstock pipe start near surge shaft to connect powerhouse at lower level. First a small-diameter pilot hole is drilled to the lower level, the diameter of this hole is typically $230 \mathrm{~mm}-445$ $\mathrm{mm}$, large enough to accommodate the drill string. Once the drill has break through into the target power house level, the bit is removed and a reamer head, of the required big diameter of the excavation, is attached to the drill string and raised back towards the machine. The drill cuttings from the reamer head fall to the floor of the lower level. The finished raise has smooth walls and may not require rock bolting or other forms of ground support depending on rock mass conditions and seepage. However, rock support is essential in fault, shear/ weak zones, and fractured zone with seepage. Therefore shaft excavation by this method is challenge in fault, shear/weak zones with seepage.

Raise boring method successfully applied in short shaft excavation of Chameliya but had not succeeded in Upper Tamakoshi for deep shaft due to deviation of pilot-hole drilling.

\section{ROCK SUPPORT}

Necessity of rock support, mostly temporary, depends on the rock mass quality, presence of shear zones, faults and groundwater. If rock mass is extremely poor and not self supporting in presence of seepage than rock support is prerequisite to stabilize. Conventional Alimak and shaft sinking methods rock support can be provided during excavation whereas there is no provision for rock support in 
mechanised raise boring method. Grouting can be done to strengthen extremely poor rock mass and secure stability after pilot hole drilling. However, it is not easy to carry out grouting in large size long/deep shaft and requires special technology for grouting. Rock support can be done after reamering into full size but depends on stand up time of extremely poor rock mass. It is very important to provide rock support on time, i.e. within stand up time for stability of shaft. Hence, raise boring method is normally suitable in good rock mass without major shear zones and faults with seepage.

\section{GEORISKS AND CHALLENGES}

Common georisks during shaft excavation are water ingress, overbreak, collapse and flowing ground. Major challenges during shaft excavations are:

- Prediction of faults, shear/weak zones, problematic zone and ground water condition,

- Deep (>200 m) and large size shaft excavation,

- Selection and availability of methods,

- Mucking from bottom to top for shaft sinking without pilot hole,

- Construction of pilot hole for deep shaft,

- Limited working space and limited capacity for transportation of supporting materials for Alimak climber,

- Poor ventilation, difficult to work, high safety hazards for workers and poor visibility during dry shotcreting for Alimak climber,

- Longer time taken to transport workers and support materials for greater than $200 \mathrm{~m}$ shaft in Alimak Climber,

- Providing rock support on time for Alimak climber and Raise boring methods,

- Risk of long pilot hole deviation for raise boring in very strong rock,

- Difficult to provide rock support in shear/weak zone, seepage on time in Raise boring, and

- Safety of crews.

\section{CASE STUDIES}

Case studies of some hydropower projects are briefly discussed below to elucidate the problems encountered in the shaft excavation.

\section{Khimti Hydropower Project (60 MW)}

Khimti I Hydropower Project, located in Dolakha district, is the $680 \mathrm{~m}$ high head project. The total length of underground pressure shaft is $1014 \mathrm{~m}$ and diameter is $2.6 \mathrm{~m}$. Inclined $\left(45^{\circ}\right)$ pressure shaft is $914 \mathrm{~m}$ long and horizontal pressure shaft is $100 \mathrm{~m}$ long. For the excavation purposes the pressure shaft is divided into lower and upper pressure shaft (Fig. 1) making
$334 \mathrm{~m}$ long Adit 5 in the middle of the section. Lower pressure shaft (LPS) was excavated from Powerhouse area whereas Upper pressure shaft (UPS) was excavated from Adit 5. The excavation was carried out by drill and blast method with the help of Alimak raise climber from bottom to top. A $674 \mathrm{~m}$ long LPS was excavated successfully with average progress rate of $7 \mathrm{~m}$ per week and completed within defined schedule without a problem. But $640 \mathrm{~m}$ long UPS excavation was completed after 3 years (excavation started on 1 October 1996 and completed on 26 June 1999) due to 3 major overbreaks followed by other small overbreaks. The overbreak section was stabilised by umbrella grouting with spilling and the section was supported by reinforced ribs of shotcrete.

\section{Geology}

In UPS section there is a fault boundary between augen gneiss and granitic gneiss (Fig. 1). The section is influenced by several minor thrust faults characterised by very weak sheared schist with clay gouge and highly sheared and fractured granitic gneiss running parallel to the foliation plane (Sunuwar et al. 1996). In general granitic gneiss is slightly to moderately weathered, grey, coarse grained, strong to medium strong and jointed. Faults in granitic gneiss are characterised by fractured and sheared, medium strong gneiss with silty sand gouge. Due to shearing effect the fault zones are porous and acts like an aquifer. The foliation and angle of dip vary from $\mathrm{N} 50^{\circ} \mathrm{E}\left(050^{\circ}\right)$ to $\mathrm{S} 80^{\circ} \mathrm{E}\left(100^{\circ}\right)$ and $45^{\circ}$ to $60^{\circ}$ due $\mathrm{N}$ respectively. The tunnel is driving perpendicular to the foliation with steeply dipping which is very favourable condition.

\section{Overbreak problem}

First original design UPS had catastrophic overbreak on 19 April 1997 after $186 \mathrm{~m}$ excavation. The shaft was abandoned and a new UPS had design $50 \mathrm{~m}$ horizontally ahead from the abandoned shaft. Again second catastrophic overbreak had occurred on 14 July 1998 at chainage $352 \mathrm{~m}$ and totally filled UPS section by overbreak debris including horizontal Adit up to $200 \mathrm{~m}$. At the time of overbreak the shaft was excavated $70 \mathrm{~m}$ from top of Adit 4 and only $20 \mathrm{~m}$ long section remained for excavation. This $20 \mathrm{~m}$ overbreak section was stabilised by umbrella grouting and supported by reinforced ribs of shotcrete with pattern of rock bolts. The progress was 1 to $2 \mathrm{~m}$ per week but the method was very effective. It took 4 months to stabilise the $20 \mathrm{~m}$ long overbreak section. The stuck debris was cleared on 17 December 1998 but third major overbreak was observed from chainage 125 to $140 \mathrm{~m}$. The same process of umbrella grouting and reinforced ribs of shotcrete was applied to stabilise the $15 \mathrm{~m}$ long overbreak. Different overbreaks and their location date of occurrence, size, cause and remedial measures are presented in Table 1.

A sinkhole was appeared at the surface $105 \mathrm{~m}$ above the second overbreak $27 \mathrm{~m}$ west of alignment (Fig. 2), which was consequence of catastrophic overbreak after almost 1 year (17 June 1999). This sinkhole was filled by tunnel muck. 
Table 1: Major overbreak record of the Khimti Hydropower Projects (Sunuwar 2004).

\begin{tabular}{|c|c|c|c|c|}
\hline Location & Date of occurrence & Size (lxbxh) $\mathbf{m}^{3}$ & Causes & Remedial measures \\
\hline $\begin{array}{l}\text { Adit } \mathbf{5} \\
\text { Old upper pressure } \\
\text { shaft } \\
\text { Ch. } 186 \text { m onwards }\end{array}$ & $\begin{array}{l}\text { Catastrophic } \\
\text { overbreak on } 19 \\
\text { April } 1997\end{array}$ & $\begin{array}{l}\text { Difficult to } \\
\text { estimate }\end{array}$ & $\begin{array}{l}\text { - } 2 \text { litre per second (lps) seepage, } \\
\text { - fault characterised by fractured and } \\
\text { sheared, blocky gneiss with clay } \\
\text { bands, } \\
\text { - Difficult working place for quick } \\
\text { support and back up. }\end{array}$ & $\begin{array}{l}\text { Abandoned the shaft and } \\
\text { changed new alignment } \\
50 \text { m inside from the } \\
\text { abandoned shaft. }\end{array}$ \\
\hline $\begin{array}{l}\text { New upper pressure } \\
\text { shaft } \\
\text { Ch. 352-364 m }\end{array}$ & $\begin{array}{l}1^{\text {st }} \text { Overbreak on } \\
14 \text { July } 1998 \text { and } \\
\text { sink hole formed at } \\
\text { surface on } 17 \text { June } \\
\text { '99. } \\
\\
2^{\text {nd }} \text { overbreak on } 17 \\
\text { Dec., } 1998 .\end{array}$ & $12 \times 15 \times 100$ & $\begin{array}{l}\text { - 6-8 lps seepage, } \\
\text { - fault characterised by fractured and } \\
\text { sheared, blocky gneiss with clay } \\
\text { bands, } \\
\text { - Difficult area for quick support and } \\
\text { back up. } \\
\text { - Could not release hydrostatic } \\
\text { pressure due to sudden flowing } \\
\text { down of stuck muck in the shaft } \\
\text { and sucked down. } \\
\text { - Insufficient support and damaged } \\
\text { by } 1^{\text {st }} \text { overbreak. } \\
\text { - Generated by } 1^{\text {st }} \text { and } 2^{\text {nd }} \\
\text { overbreaks. }\end{array}$ & $\begin{array}{l}\text { - Excavation from Adit } 4, \\
\text { top to down. } \\
\text { - Grouting and spiling in } 20 \\
\text { cm spacing. } \\
\text { - } 1 \text { m excavation by cutting } \\
\text { at upper section and } \\
\text { shotcreting. } \\
\text { - Reinforce ribs of shotcrete } \\
\text { in upper section. } \\
\text { - Excavation at lower } \\
\text { section including invert } \\
\text { and supported by reinforce } \\
\text { ribs of shotcrete. }\end{array}$ \\
\hline
\end{tabular}

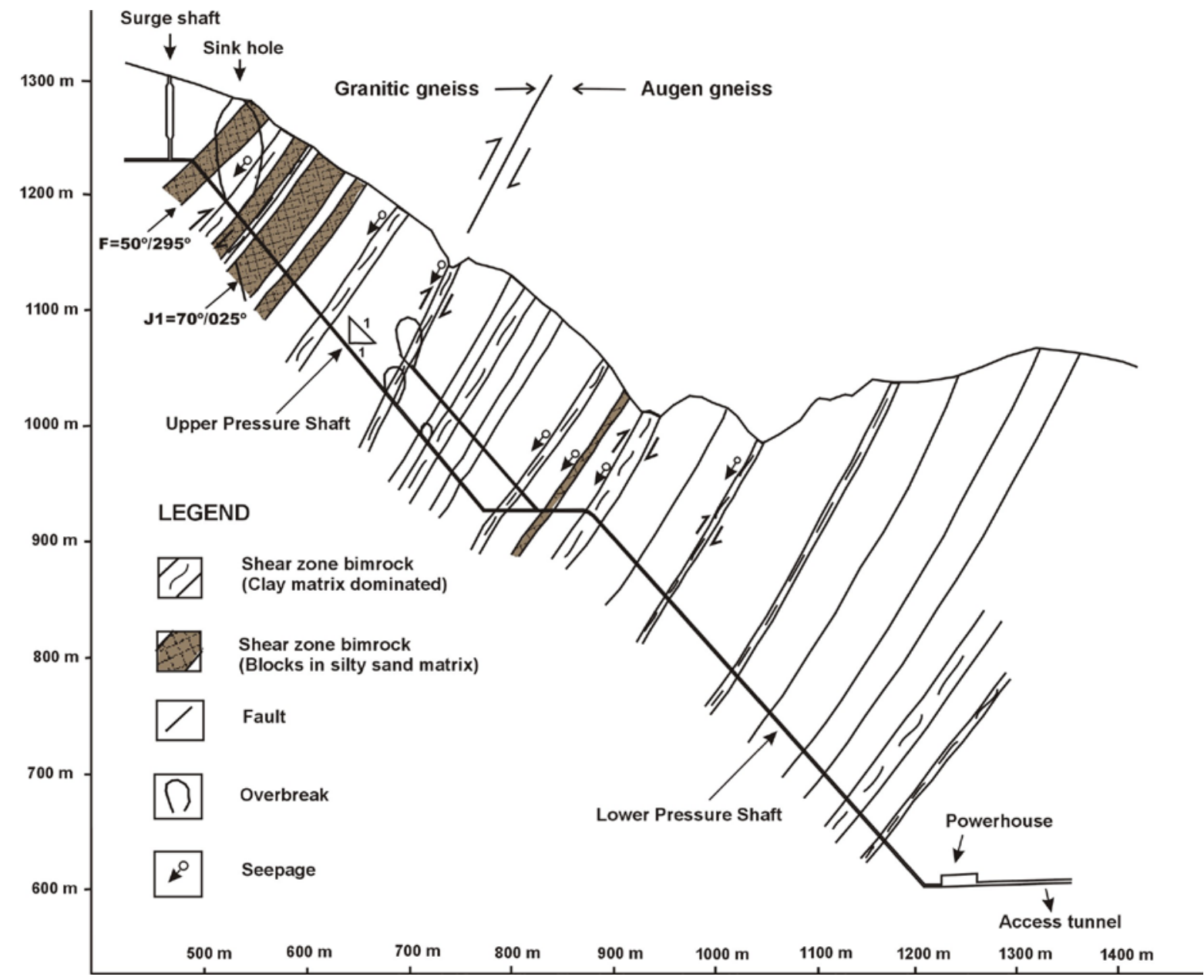

Fig. 2: Engineering geological section along the inclined pressure shaft in Khimti project showing overbreaks. 


\section{Excavation method}

The excavation was carried out by drill and blast method with Alimak raise climber. Excavation had carried out mainly from bottom to top and lesser from top. An Alimak rail with working plate form was used to excavate and transport equipment, supporting materials and workers at working face. Hand drill hammer was used. Maximum pull length was $1.5 \mathrm{~m}$. Average progress was $7 \mathrm{~m}$ per week. Dry fibre reinforced shotcrete, swellex and grouted rock bolts were used for temporary support. Due to high water pressure and poor geological condition steel lining was designed for final lining. It is found that inclined shaft excavation from bottom to top by Alimak rail is very difficult and risky. In addition this method is only suitable for shorter length i.e. less than $200 \mathrm{~m}$.

\section{Causes of overbreak}

The main causes of overbreak are extremely poor rock condition characterised by jointed, fractured and sheared, weak to strong granitic gneiss containing silty sand with considerable amount of seepage. In addition, technical difficulties for providing support within stand-up time. Due to fractured, jointed and sheared nature of rock, especially in fault area considerable amount of ingress groundwater (6-8 lpm) was present. The groundwater had eroded joint filling silty sand and loosened individual blocks. These blocks were gradually separated and started to fall. As a result overbreak occurred in a form of ravelling. In addition where face was supported by fibre reinforced shotcrete a build up pore water pressure initiated overbreak. Technical difficulties such as limited working space, long time taken to reach and transport supporting equipment/materials at working place and safety concern are drawbacks which made impossible to provide support within stand up time. For example, it took 40 minutes to reach and come back $350 \mathrm{~m}$ distance by Alimak.

\section{Nature of overbreak}

Overbreak followed conical shape, which is controlled, by foliation $\left(50^{\circ} / 295^{\circ}\right)$ at bottom side and the joint $\left(70^{\circ} / 025^{\circ}\right)$ at upper side (Fig. 2). Overbreak was occurred by sliding along the foliation plane combined with the steep joint forming a wedge shape due to separation of individual blocks by erosion of ground water. At first considerable amount of seepage was appeared and fractured and sheared rock blocks/fragments was started to fell down in a form of ravelling. Suddenly huge amount of sluggish debris rush down in high speed and completely filled excavated section. The overbreak was gradually migrated upwards-forming conical shape as shown in Fig. 2.

\section{Remedial measures}

The $20 \mathrm{~m}$ overbreak section in UPS was stabilised by umbrella grouting and the section was supported by reinforced ribs of shotcrete with pattern of rock bolts in $1 \mathrm{~m}$ spacing including invert making circular shape. The umbrella grouting was carried out with $6 \mathrm{~m}$ long perforated GI spiling pipes in 20 $\mathrm{cm}$ spacing from top portion. The grout pressure 3 to 4 bar was applied depending on the nature of debris in order to minimise overflow of grouting slurry. Debris material is characterised by silty sand with boulders/gravels of granitic gneiss. After grouting $1 \mathrm{~m}$ long excavation was carried out at top portion by hand cutting. $10 \mathrm{~cm}$ thick fibre reinforced shotcrete was sprayed and ribs of T16 rebars in $10 \mathrm{~cm}$ spacing were erected with the help of grouted rock bolts in $1 \mathrm{~m}$ spacing. Erected ribs were covered by another layer of shotcrete. Similarly bottom portion was excavated and supported by extending ribs making circular shape including invert (Fig. 3).

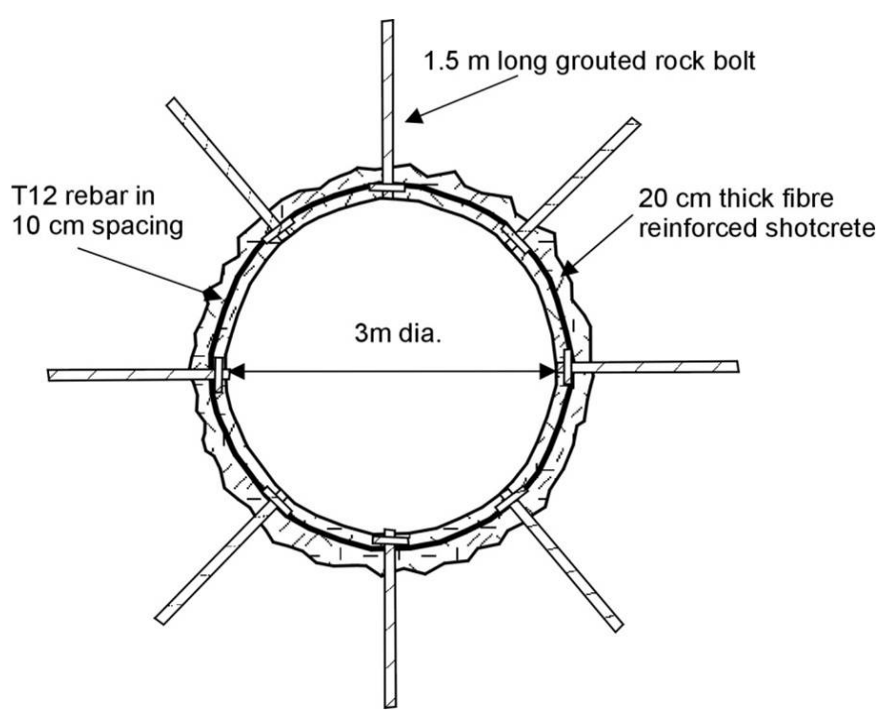

Fig. 3: Reinforced ribs of shotcrete applied in the overbreak section.

Ingress water was pumped out continuously. After $3 \mathrm{~m}$ long excavation another set of umbrella grouting was carried for overlapping. The progress was 1 to $2 \mathrm{~m}$ per week but the method was very effective. It took 4 months to stabilise the $20 \mathrm{~m}$ long overbreak section. The same type of support system was adopted in the other overbreaks. It is found that the process of umbrella grouting with spilling and supporting by reinforced ribs of shotcrete is more effective in over break area although the method was sluggish.

\section{Upper Tamakoshi Hydroelectric Project (456 MW)}

Upper Tamakoshi Hydroelectric Project, located in Dolakha district, has $822 \mathrm{~m}$ gross head. Total length of underground penstock shaft is $683 \mathrm{~m}$. For excavation purpose the penstock shaft is divided in to Upper and Lower by introducing a Adit at the middle. Upper penstock shaft is 310 $\mathrm{m}$ high with $4.4 \mathrm{~m}$ diameter whereas $373 \mathrm{~m}$ lower penstock shaft of $2.1 \mathrm{~m}$ diameter. Upper and lower penstock shafts were excavated by both shaft sinking and Alimak raise climber methods. Raise boring method had tried at the beginning but could not succeed due to deviation of pilot hole.

\section{Geology}

The shaft area consists of schist and gneiss of Higher Himalaya. Schist is represented by thick-banded to massive, light grey to dark grey, medium to coarse-grained, strong 
to very strong mica/feldspathic schist and banded gneiss. Rock mass is very good quality and favourable condition for tunnelling. Foliation is major critical joint and attitude is < $35^{\circ} / 010^{\circ}$ (dip/direction).

\section{Shaft Excavation and challenges}

Mechanised Raise boring method was selected based on the good rock mass quality. This method had tried but drilled pilot holes were deviated 7 times and could not reach in lower planned point. Hence the raise boring method could not succeed. Then excavation was started by Shaft sinking method from top to bottom to meet the planned progress (Fig. 4).

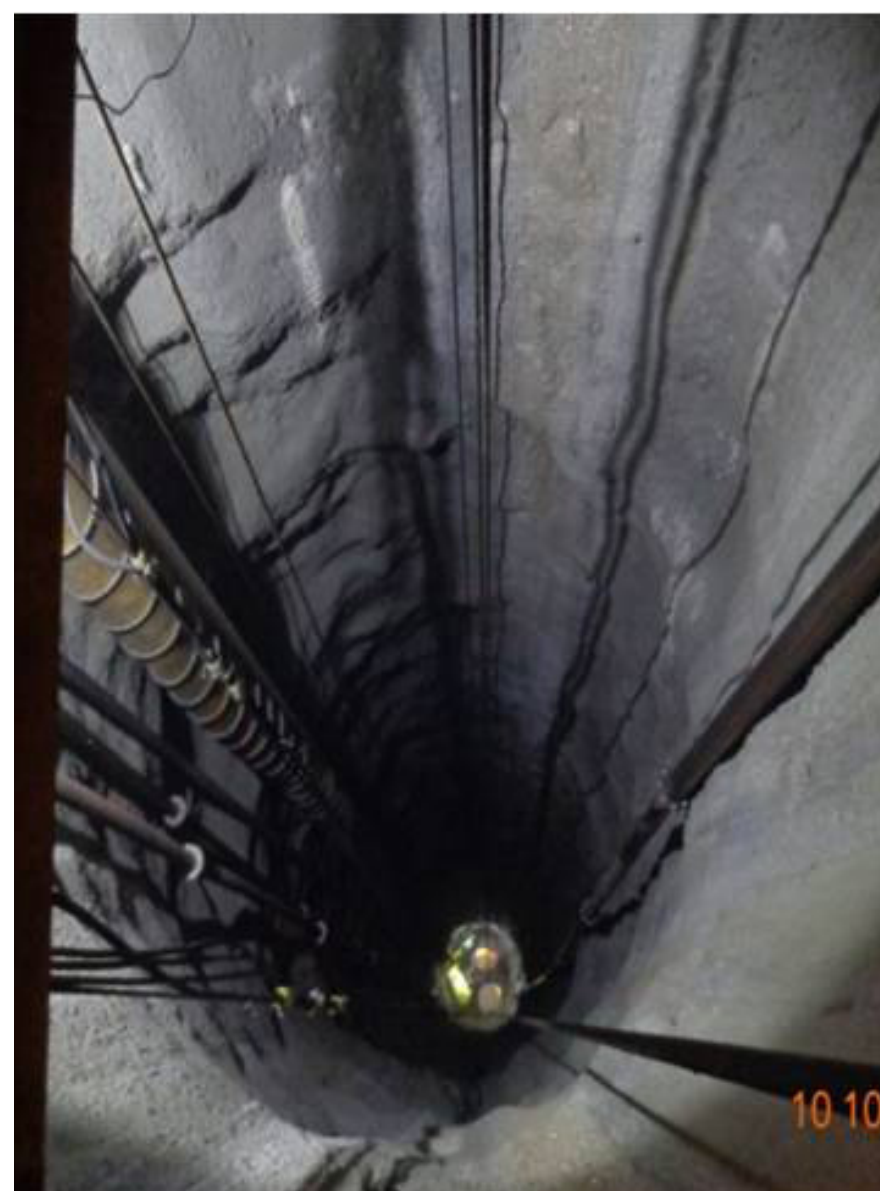

Fig. 4: Vertical shaft excavated by shaft sinking method (Bhandari, 2014).

Progress rate of this method was $1 \mathrm{~m}$ /day which was slow. Hence Alimak raise climber, from bottom to top, was introduced. Excavation rate was $1.8 \mathrm{~m}$ /day which is almost double than Shaft sinking method. Finally excavation of 310 $\mathrm{m}$ and $373 \mathrm{~m}$ deep shaft by shaft sinking method from top and Alimak raise climber from bottom was completed without major problems.

\section{Chameliya Hydroelectric Project (30 MW)}

Chameliya Hydroelectric Project, located in Darchula District, has $72 \mathrm{~m}$ high pressure shaft of $4.9 \mathrm{~m}$ diameter and
$300 \mathrm{~m}$ horizontal penstock tunnel. Excavation of the shaft was carried out by combination of raise boring and shaft sinking methods only after completion of horizontal penstock tunnel at bottom and headrace tunnel from surge adit at top. Flowing ground with debris flow georisks were occurred during excavation of the shaft.

\section{Geology}

The shaft area consists of dolomite, phyllite and slate of Lesser Himalaya. Dolomite is dominant and is moderately weathered, grey, fine grained, strong, jointed and fractured. Slate and phyllite are intercalated. The slate is black, fine to medium grained, slightly weathered, thinly foliated, jointed and fractured whereas phyllite is grey to black, fine grained, thinly foliated, moderately weathered/ decomposed and weak. Bedrock consists of 3 sets of planar smooth to rough, nonpersistence to persistence, tight to open joint with talc/clay filling along the foliation.

The rock mass of the area is influenced by several minor 0.5 to $1.5 \mathrm{~m}$ thick shear zones which consist of shear rocks with talc and clay bands. In addition, groundwater conditions in the area are wet to dripping condition. Rock mass is very poor to extremely poor due to presence of shear zones, water and 3 sets of joints.

\section{Excavation method}

Seventy two meter high and $4.9 \mathrm{~m}$ diameter pressure shaft was excavated by combination of raise boring and shaft sinking method. Raise boring method was used to make pilot hole of $1.4 \mathrm{~m}$ diameter. At first $200 \mathrm{~mm}$ Pilot hole drilled from top to bottom and was $1.4 \mathrm{~m}$ diameter upward reaming by raise boring. Finally, widenen to $4.9 \mathrm{~m}$ by drill and blast with shaft sinking method from top to bottom utilizing mucking and dewatering through the $1.4 \mathrm{~m}$ pilot hole.

\section{Problems and remedial measures}

Flowing ground with debris flow was encountered at 18 $\mathrm{m}$ height from a small hole in the shaft during widening of the pilot hole (Fig. 5). Debris consists of crush fragments of dolomite, slate and phyllite. About $1,000 \mathrm{~m}^{3}$ debris was cleared and created a cavity (size $25 \mathrm{~m} \times 8 \mathrm{~m} \times 5 \mathrm{~m}$ ) inclined at $65^{\circ}$. Bedrock were exposed at walls and crown of the cavity which indicates shear zone debris was fully saturated with ground water storing for many years. Balloon of saturated debris was intersected during widening of pilot hole and hence all the stored debris flown out through this opening. Further debris flow was stopped and naturally stabilized by forming conical shaped cavity. It was easier to start support work and sealing the cavity.

The mouth of the cavity was sealed by $2 \mathrm{~m}$ thick pumped concrete with further back filled by grouting. 


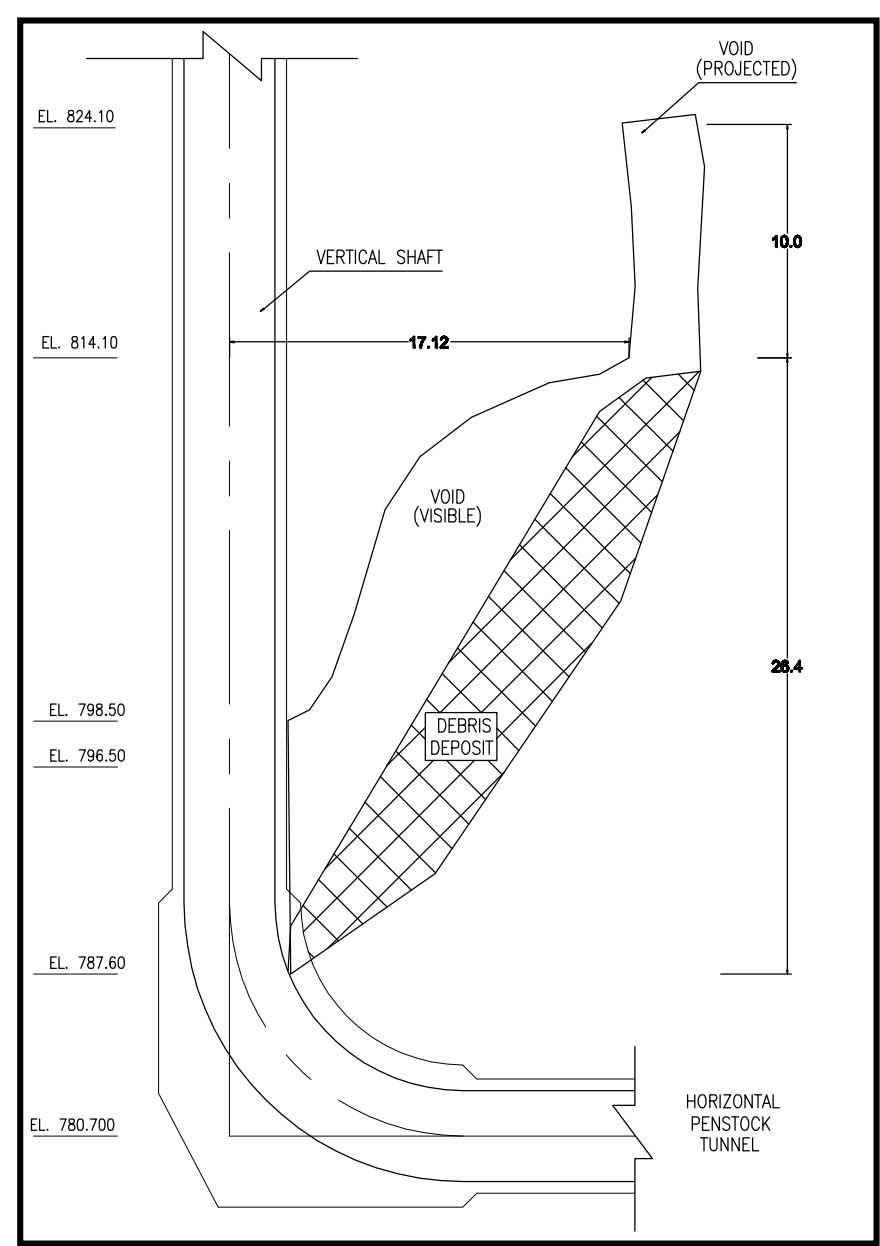

Fig: 5. Cavity created due to flowing ground (Shah, 2014).

\section{CONCLUSIONS}

- Shaft excavation greater than $200 \mathrm{~m}$ depth is challenge in Nepal Himalaya.

- Georisks such as overbreaks, flowing ground and water ingress pose by fault, shear/weak zones, and seepage.

- Construction of accurate geological model showing faults, shear zones and ground water condition is urgent.

- Alimak raise climber method used for small size and deep shaft excavation. Shaft sinking method with pilot hole normally select for large size and short shaft excavation.

- Modern Raise boring method is faster and safer but challenge in shear zone and fault with seepage.

\section{RECOMMENDATIONS}

To minimise georisks and challenges, the following are recommended:

- To construct precise geological model identifying fault, shear/weak zones and ground water condition and predict georisks,

- To select suitable layout and alignment in better geology to optimise georisks,

- To make proper plan and select suitable excavation method and technologies to tackle predicted georisks,

- To plan for shorter shaft if geology is poor and difficult to tackle georisks, and

- To select experienced manpower and contractor.

\section{REFERENCES}

Bhandari, B. K., 2014, Underground excavation at Upper Tamakoshi Hydroelectric Project (456 MW)- a case study in site investigation, design and construction. Presented in Nepal Tunnelling Conference 2014, 19-20 December 2014.

Harris, N. and Whalley, J., 2001, Mountain Building, Block 4, The Open University, U.K., 165 p.

Kizaki, K., 1994, A outline of the Himalayan upheaval: A case study of the Nepal Himalayas. Published by Japan International Co-operation Agency (JICA), pp. 32-33.

Shah, S., 2014, Underground excavation at Chameliya Hydroelectri Project: Case study. Presented in Nepal Tunnelling Conference 2014, 19-20 December 2014.

Sunuwar, S. C., and O'Neill, B., 1996, Tunneling in Khimti Hydropower Project, central Nepal.” Jour. Nepal Geol. Soc., v. 13, pp. 109-120.

Sunuwar, S. C., 2004, Geological problems in the hydropower development of Nepal: case studies, Seminar Papers Disaster Management in Nepal, Nepal Engineers' Association, April 11-12, 2004, Kathmandu, pp. 130141.

Sunuwar, S. C., 2003, Overbreak problem in the inclined pressure shaft of the Khimti I Hydropower Project in Nepal, World Tunnelling, v. 16(6), pp. 241-242.

Upreti, B. N. and Le Fort, P., 1999. Lesser Himalayan Crystalline Nappes of Nepal: Problems of their origin. Geol. Soc. Am. Bull., Sp. Issue. No. 328, pp. 225-237. 